\title{
Control of Nausea and Vomiting in Patients Receiving Anthracycline/Cyclophosphamide Chemotherapy for Breast Cancer
}

\author{
MINAKO NAWA-NISHIGAKI ${ }^{1}$, RYO KOBAYASHI $^{1}$, AKIO SUZUKI $^{1}$, \\ CHIEMI HIROSE ${ }^{1}$, RIE MATSUOKA ${ }^{1}$, RYUTARO MORI ${ }^{2}$, MANABU FUTAMURA ${ }^{2}$, \\ TADASHI SUGIYAMA ${ }^{3}$, KAZUHIRO YOSHIDA ${ }^{2}$ and YOSHINORI ITOH ${ }^{1}$ \\ ${ }^{1}$ Department of Pharmacy, Gifu University Hospital, Gifu, Japan; \\ ${ }^{2}$ Department of Surgical Oncology, Gifu University Graduate School of Medicine, Gifu, Japan; \\ ${ }^{3}$ Laboratory of Pharmacy Practice and Social Science, Gifu Pharmaceutical University, Gifu, Japan
}

\begin{abstract}
Background/Aim: Chemotherapy-induced nausea and vomiting (CINV) is one of most distressing adverse events during cancer chemotherapy. In breast cancer patients receiving anthracycline and cyclophosphamide (AC) chemotherapy, CINV is poorly controlled. Patients and Methods: The prevalence of guideline-consistent antiemetic medication and control of CINV were investigated retrospectively in breast cancer patients receiving the first cycle of AC chemotherapy. Risks for CINV were analyzed by the multivariate logistic regression analysis. The effect of olanzapine added to the standard antiemetic medication on the incidence of CINV was subsequently evaluated in separate patients who received the first cycle of AC chemotherapy. Results: Although the guideline-consistent antiemetic medication was performed in all subjects, the control rate of nausea (32\%), but not vomiting (78\%) was low. Risk analysis indicated that age younger than 55-year-old was a significant factor that reduces the control of both nausea and vomiting. Olanzapine ( $5 \mathrm{mg} /$ day for 5 days), when added to the standard three-drug antiemetic medication, significantly improved the control of nausea and complete response. Conclusion: CINV was poorly controlled in breast cancer patients receiving $A C$ chemotherapy, in which age younger than 55-year-old was a significant risk for both nausea and vomiting. Olanzapine was effective for improvement of the control of CINV associated
\end{abstract}

This article is freely accessible online.

Correspondence to: Ryo Kobayashi, Department of Pharmacy, Gifu University Hospital, 1-1 Yanagido, Gifu 501-1194, Japan. Tel: +81 582306000, e-mail: ryo_k@gifu-u.ac.jp

Key Words: Anthracycline and cyclophosphamide chemotherapy, breast cancer, CINV, olanzapine. with AC chemotherapy. Therefore, care should be taken to prevent CINV in young patients receiving AC chemotherapy by adding olanzapine to the standard three-drug antiemetic medication.

Chemotherapy-induced nausea and vomiting (CINV) is one of the most distressing problems for cancer patients. This adverse event impairs patients' quality of life and exerts a negative influence on patient's desire to continue the chemotherapy $(1,2)$.

Breast cancer is the most prevalent cancer in women worldwide. Combination of anthracycline with cyclophosphamide (AC) has been commonly used for breast cancer as neoadjuvant chemotherapy, adjuvant chemotherapy, or metastatic/recurrent chemotherapy (3). The AC chemotherapy is classified as high-emetic risk chemotherapy (HEC) according to several clinical practice guidelines for antiemesis, including the American Society of Clinical Oncology (ASCO) (4), the National Comprehensive Cancer Network (NCCN) (5), the Multinational Association of Supportive Care in Cancer (MASCC)/European Society for Medical Oncology (ESMO) (6), and the Japanese Society of Clinical Oncology (JSCO) (7). The guidelines recommend the use of the three-drug antiemetic regimen for prevention of CINV associated with HEC, in which neurokinin-1 (NK1) receptor antagonist, dexamethasone and 5-HT3 receptor antagonist are treated on day 1, the combination of NK1 receptor antagonist and dexamethasone is administered on days 2 and 3, and dexamethasone is given on day4 (4-7). However, the control of CINV associated with AC chemotherapy is not necessarily sufficient, even when the guideline-consistent three-drug antiemetic premedication is implemented. Particularly, the rate of no nausea is too low (31$49 \%)(8-12)$ compared to the rate of no vomiting (55-92\%) (9$12,13-16)$. We also previously reported that $\mathrm{AC}$ chemotherapy for breast cancer is most emetogenic among various 
chemotherapy regimens that were carried out in the outpatient setting, in which the odds ratio (OR) for incidence of CINV is 4.955 [95\% confidence interval $(\mathrm{CI})=1.863-13.18 ; p=0.001]$ (17). Therefore, additional antiemetic agents with different mechanisms may be required for prevention of nausea associated with $\mathrm{AC}$ chemotherapy for breast cancer.

Olanzapine is an atypical antipsychotic drug that possesses an appetite stimulating actionis (18). Navari et al. (19) reported by a phase III study comparing the antiemetic effect between olanzapine and aprepitant, when used in combination with palonosetron and dexamethasone, in chemotherapy-naive patients receiving cisplatin $\geq 70 \mathrm{mg} / \mathrm{m}^{2}$ or cyclophosphamide $\geq 500 \mathrm{mg} / \mathrm{m}^{2}$ and doxorubicin $\geq 50 \mathrm{mg} / \mathrm{m}^{2}$ that olanzapine (10 mg/day, days 1-4) is similar to aprepitant in the rate of complete response but is more effective than aprepitant in preventing delayed nausea. Based on these findings, the NCCN guideline has recommended the use of olanzapine in combination with paronosetron and dexamethasone as one of the optional antiemetic medication for HEC and moderate emetic-risk chemotherapy (MEC) since 2014.

In the present study, the control rate and the risk factors of CINV were investigated in patients receiving the first cycle of AC chemotherapy for breast cancer. Subsequently, the additional effect of olanzapine on the control of CINV was examined.

\section{Patients and Methods}

Patients. The prevalence of antiemetic medication, the control rate of CINV, and risk factors that affect the incidence of CINV were investigated in 73 breast cancer patients who received the first cycle of AC chemotherapy during a period between January 2010 and December 2014. Subsequently, the effect of olanzapine was examined in 19 patients receiving the same chemotherapy regimen during a period from February 2015 to March 2016. The present study was carried out in accordance with the guidelines for the care for human study adopted by the Ethics Committee of the Gifu Graduate School of Medicine, and notified by the Japanese Government (approved no. 26-153 of the Institutional Review Board).

Antiemetic medication. For standard antiemetic medication, the combination of aprepitant (125 mg, orally), an NK1 receptor antagonist, granisetron ( $3 \mathrm{mg}$, intravenously) and dexamethasone $(9.9 \mathrm{mg} /$ day, intravenously) was administered on day 1 before chemotherapy, and two-drug combination such as aprepitant ( $80 \mathrm{mg}$, orally) and dexamethasone ( $4 \mathrm{mg}$, orally) was treated on days 2 and 3 , and dexamethasone (4 mg, orally) was given on day 4 .

Evaluation of the control of CINV. The control of CINV was evaluated as the rates of no nausea, no significant (grade 2 and more) nausea, no vomiting, complete response (no vomiting and no rescue) and complete control (no nausea, no vomiting and no rescue) during acute (within 24 hours after chemotherapy), delayed (24-120 hours), and overall (0-120 hours) periods.

Risk analysis for CINV. Demographics of patients who received the first cycle of AC chemotherapy were compared in patients with or without nausea as well as in those with or without vomiting during overall period. Risk factors for nausea or vomiting were determined by univariate and multivariate logistic regression analyses. OR and 95\% CI were determined. The cut-off values for age, body mass index (BMI) and serum creatinine level were determined by the Youden index method in the receiver operating characteristic curve (ROC) analysis, in which the Youden index was calculated as the maximum value of (sensitivity + specificity -1 ), according to the methods described earlier $(20,21)$.

Effect of olanzapine. In another set of study, the effect of olanzapine ( $5 \mathrm{mg}$, orally, on days 1-5), when included in the standard three-drug antiemetic medication, on the control rates of CINV was examined in 19 patients receiving the first cycle of AC chemotherapy during February 2015 and March 2016. Data were compared with those obtained from different 73 patients who received the same chemotherapy during January 2010 and December 2014. Olanzapine $(5 \mathrm{mg} /$ day) was administered orally for 5 days (day 1 -day 5 ).

Statistical analyses. Data were analyzed by using IBM SPSS Statistics ver. 22 (IBM Japan Services Co., Ltd., Tokyo, Japan). Parametric variables were statistically compared by $t$-test, while nonparametric data were analyzed by Mann-Whitney $U$-test or chisquare test. Kruscal-Wallis test was used for non-parametric analysis of variance. $p$-Values of less than 0.05 were considered statistically significant.

\section{Results}

Prevalence of guideline-consistent antiemetic medication and the rate of $C I N V$. The prevalence of guideline-consistent antiemetic premedication was $100 \%$ during acute and delayed periods in patients receiving the first cycle of AC chemotherapy. Even under the standard antiemetic premedication, complete response was $63 \%, 51 \%$ and $48 \%$ during acute, delayed and overall periods, respectively (Figure 1). The complete control was poor (55\% for acute, $33 \%$ for delayed, and $32 \%$ for overall periods). Although vomiting was well controlled ( $84 \%$ for acute, $86 \%$ for delayed and $78 \%$ for overall periods), the rates of no nausea were severely depressed to $33 \%$ and $32 \%$ during delayed and overall periods, respectively.

Comparison of demographics between patients with CINV and those without CINV. As shown in Table I, nausea occurred in 50 patients $(69 \%)$. Age was younger and smoking was less prevalent in patients with nausea than in those without nausea (52.0 years old versus 58.9 years old, $p=0.014 ; 4.0 \%$ versus $42.1 \%, p<0.001)$. On the other hand, vomiting appeared in 16 patients $(22 \%)$, in which age was again significantly younger than in patients without vomiting (46.9 years old versus 56.2 years old, $p=0.0004)$. Interestingly, body mass index was significantly lower in patients with vomiting $(20.5 \pm 1.8$ versus $22.3 \pm 4.1, p=0.011)$. Serum creatinine level was also lower in case vomiting occurred.

Risk analysis for CINV. The cut-off values calculated from Youden index method of ROC analysis were 56.5 years old for 


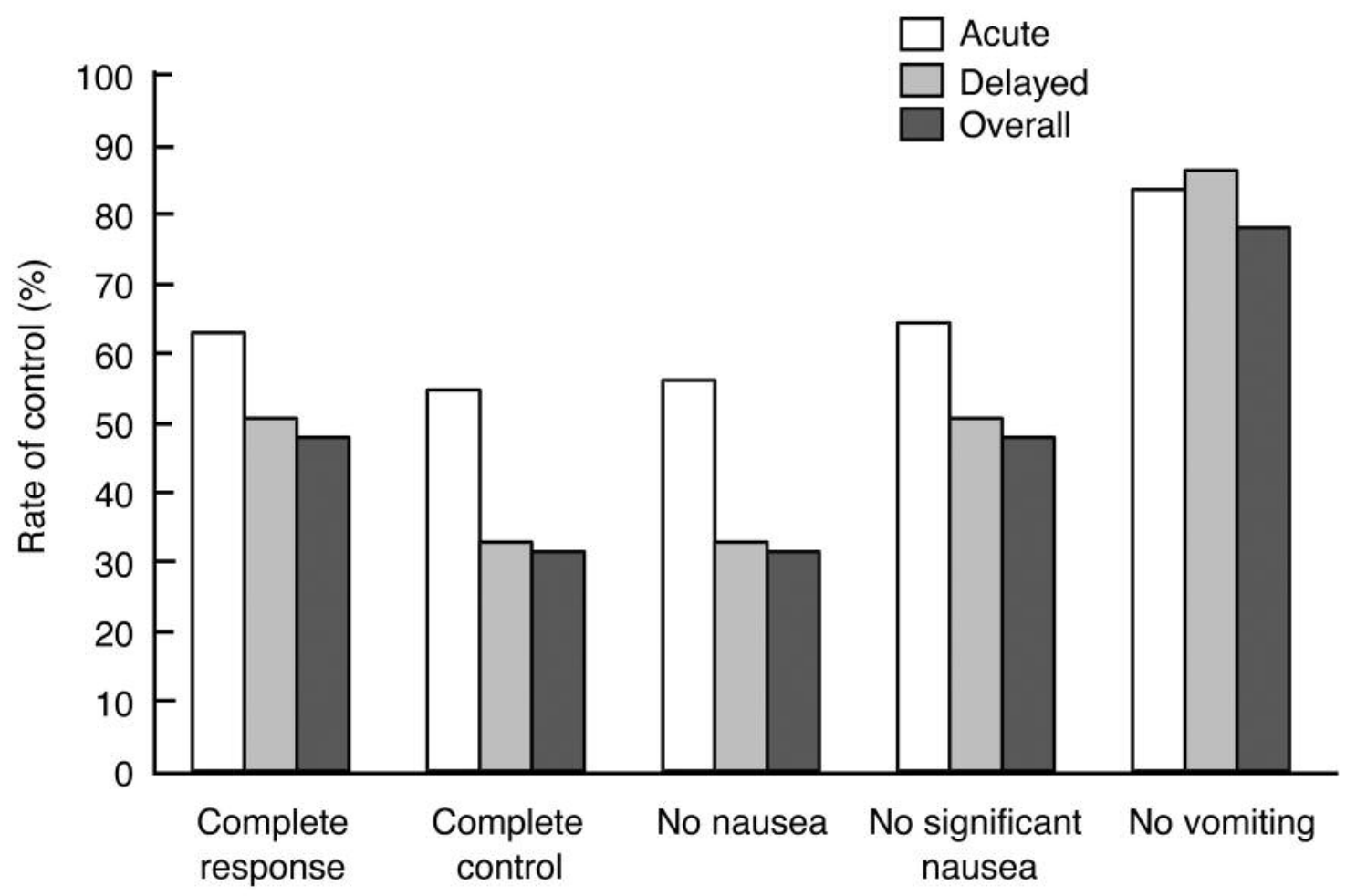

Figure 1. Complete response, complete control, rate of no nausea, rate of no significant nausea and rate of no vomiting during acute, delayed and overall periods in 73 patients who received the first cycle of anthracycline /cyclophosphamide (AC) chemotherapy for breast cancer. Patients were all pretreated with granisetron ( $3 \mathrm{mg} /$ day on day 1$)$, dexamethasone (12 $\mathrm{mg}$ intravenously on day 1 and $8 \mathrm{mg} /$ day orally on days $2-4)$ and oral aprepitant (125 mg/day on day 1 and $80 \mathrm{mg} /$ day on days 2-3).

nausea and 53.5 years old for vomiting, 22.7 for body mass index and $0.58 \mathrm{mg} / \mathrm{dl}$ for serum creatinine level in case of vomiting. In the present study, the cut-off values were set to 55 years old, 23 for body mass index, and $0.6 \mathrm{mg} / \mathrm{dl}$ for serum creatinine. As shown in Table II, univariate analysis showed that age younger than 55 years old $(\mathrm{OR}=4.623$; 95\% CI $=1.551$ $13.776, p=0.006$ ) was only a significant risk factor that reduces the control of nausea. In contrast, smoking significantly reduced the risk for nausea. On the other hand, age younger than 55 years old $(\mathrm{OR}=10.348 ; 95 \% \mathrm{CI}=2.416-49.9, p=0.004)$ and lower BMI score than $23(\mathrm{OR}=8.75 ; 95 \% \mathrm{CI}=1.077-71.066, p=0.042)$ were significant risk factor for vomiting. A multivariate analysis indicated that only age younger than 55 years old was a significant risk for nausea as well as for vomiting.

Comparison of the control of CINV between patients younger than 55 years old and those 55 years old of age and older. As shown in Table III, the rates of complete response, complete control, no nausea, no significant nausea, and no vomiting were all dramatically reduced in patients younger than 55 years old. It was notable that no patient had acute vomiting compared with 25 of 37 patients (68\%) younger than 55 years old experienced acute vomiting. The OR for control of vomiting was $0.097-0.213$, while the value for control of nausea was between 0.194 and 0.216 during the emetic risk period.

Effect of olanzapine added to the standard antiemetic medication on the control of CINV. Addition of olanzapine (day 1-5) to the standard three-drug antiemetic medication significantly improved the complete response during delayed but not acute period (Figure 2). Notably, the rate of no significant nausea but not the rate of no nausea during delayed period was significantly improved by the additional treatment with olanzapine, although the rate of no vomiting was not significantly improved by olanzapine.

\section{Discussion}

In the present study, we surveyed the rate of the control of CINV in 78 breast cancer patients who received the first cycle of AC chemotherapy. Adverse drug reactions were monitored in all patients by health professionals, including pharmacists and nurses. Additionally, we checked the prescription regarding the guideline consistent antiemetic medication and promoted appropriate use of antiemetic drugs according to the clinical practice guideline. As a consequence, the prevalence 
Table I. Comparison of patients' demographics between patients with and without nausea or vomiting after AC chemotherapy.

\begin{tabular}{|c|c|c|c|c|c|c|c|c|c|c|}
\hline \multirow[b]{2}{*}{ Age (mean, range) } & \multicolumn{2}{|c|}{$\begin{array}{l}\text { With nausea } \\
\qquad(\mathrm{N}=50)\end{array}$} & \multicolumn{2}{|c|}{$\begin{array}{l}\text { Without nausea } \\
\qquad(\mathrm{N}=23)\end{array}$} & \multirow{2}{*}{$\frac{p \text {-Value }}{0.014^{\mathrm{a}}}$} & \multicolumn{2}{|c|}{$\begin{array}{l}\text { With vomiting } \\
\text { (N-16) }\end{array}$} & \multicolumn{2}{|c|}{$\begin{array}{l}\text { Without vomiting } \\
\text { (N-57) }\end{array}$} & \multirow{2}{*}{$\begin{array}{c}p \text {-Value } \\
0.0004^{\mathrm{a}}\end{array}$} \\
\hline & $\begin{array}{c}52.0 \\
\text { mean }\end{array}$ & $\begin{array}{l}(37-74) \\
\text { S.D. }\end{array}$ & $\begin{array}{c}58.9 \\
\text { mean }\end{array}$ & $\begin{array}{l}(25-77) \\
\text { S.D. }\end{array}$ & & $\begin{array}{c}46.9 \\
\text { mean }\end{array}$ & $\begin{array}{l}(37-65) \\
\text { S.D. }\end{array}$ & $\begin{array}{c}56.2 \\
\text { mean }\end{array}$ & $\begin{array}{l}(25-77) \\
\text { S.D. }\end{array}$ & \\
\hline Body mass index & 21.6 & 3.3 & 22.6 & 4.8 & $0.334^{\mathrm{b}}$ & 20.5 & 1.8 & 22.3 & 4.1 & $0.011^{\mathrm{b}}$ \\
\hline Body surface area $\left(\mathrm{m}^{2}\right)$ & 1.53 & 0.12 & 1.48 & 0.17 & $0.269^{\mathrm{b}}$ & 1.50 & 0.10 & 1.52 & 0.15 & $0.774^{\mathrm{b}}$ \\
\hline Serum creatinine $(\mathrm{mg} / \mathrm{mL})$ & 0.56 & 0.09 & 0.57 & 0.07 & $0.709^{b}$ & 0.53 & 0.06 & 0.57 & 0.09 & $0.037^{b}$ \\
\hline Serum albumin $(\mathrm{g} / \mathrm{dL})$ & 4.30 & 0.31 & 4.39 & 0.23 & $0.234^{\mathrm{b}}$ & 4.35 & 0.26 & 4.31 & 0.30 & $0.660^{\mathrm{b}}$ \\
\hline Dose $\left(\mathrm{mg} / \mathrm{m}^{2}\right)$ & mean & S.D. & mean & S.D. & & mean & S.D. & mean & S.D. & \\
\hline Epirubicin (EPI) & 91 & 2 & 92 & 4 & $0.152^{\mathrm{a}}$ & 91 & 2 & 92 & 4 & $0.694^{\mathrm{a}}$ \\
\hline Cyclophosphamide(CPA) & 594 & 24 & 583 & 39 & $0.127^{\mathrm{a}}$ & 594 & 24 & 583 & 39 & $0.610^{\mathrm{a}}$ \\
\hline Regimens & $\mathrm{N}$ & $\%$ & $\mathrm{~N}$ & $\%$ & $0.619^{c}$ & $\mathrm{~N}$ & $\%$ & $\mathrm{~N}$ & $\%$ & \\
\hline EC (EPI 90/CPA 600) & 44 & 88.0 & 19 & 82.6 & & 15 & 93.8 & 48 & 84.2 & $0.315^{\mathrm{c}}$ \\
\hline FEC (5-FU 500/EPI 100/CPA 500) & 3 & 6.0 & 4 & 17.4 & & 1 & 6.3 & 6 & 10.5 & \\
\hline AC (DXR 60/CPA 600) & 3 & 6.0 & 0 & & & 0 & & 3 & 5.3 & \\
\hline Smoking, \% (yes/no) & $4.0 \%$ & $(2 / 48)$ & $42.1 \%$ & $(8 / 11)$ & $0.001^{\mathrm{d}}$ & $6.3 \%$ & $(1 / 15)$ & $17.0 \%$ & $(9 / 44)$ & $0.507^{\mathrm{d}}$ \\
\hline Drinking, \% (yes/no) & $16.0 \%$ & $(8 / 42)$ & $26.3 \%$ & $(5 / 14)$ & $0.526^{\mathrm{d}}$ & $31.3 \%$ & $(5 / 11)$ & $15.1 \%$ & $(8 / 45)$ & $0.279^{\mathrm{d}}$ \\
\hline Diabetes mellitus, $\%$ (yes/no) & $2.0 \%$ & $(1 / 49)$ & $5.3 \%$ & $(1 / 18)$ & $1.000^{\mathrm{d}}$ & $0 \%$ & $(0 / 16)$ & $3.8 \%$ & $(2 / 51)$ & $1.000^{\mathrm{d}}$ \\
\hline
\end{tabular}

aMann-Whitney $U$-test, ${ }^{b}$-test, cKruscal-Wallis test, ${ }^{\mathrm{d}}$ Chi-square test.

Table II. Risk factors for nausea and vomiting in patients receiving AC chemotherapy for breast cancer.

\begin{tabular}{|c|c|c|c|c|c|c|c|c|}
\hline & \multicolumn{3}{|c|}{ Univariate analysis } & \multirow[b]{3}{*}{$p$-Value } & \multicolumn{3}{|c|}{ Multivariate analysis } & \multirow[b]{3}{*}{$p$-Value } \\
\hline & \multicolumn{3}{|c|}{$95 \% \mathrm{CI}$} & & \multicolumn{3}{|c|}{$95 \% \mathrm{CI}$} & \\
\hline & OR & Lower & Upper & & OR & Lower & Upper & \\
\hline \multicolumn{9}{|l|}{ Nausea } \\
\hline Age $<55$-year-old & 4.623 & 1.551 & 13.776 & 0.006 & 4.826 & 1.567 & 14.865 & 0.006 \\
\hline Body mass index $<23$ & 1.021 & 0.349 & 2.990 & 0.970 & 0.719 & 0.223 & 2.320 & 0.581 \\
\hline Creatinine $<0.6(\mathrm{mg} / \mathrm{mL})$ & 1.366 & 0.489 & 3.814 & 0.552 & 1.144 & 0.378 & 3.464 & 0.812 \\
\hline Drinker & 0.533 & 0.150 & 1.900 & 0.332 & & & & \\
\hline Smoker & 0.057 & 0.011 & 0.308 & 0.001 & & & & \\
\hline \multicolumn{9}{|l|}{ Nausea } \\
\hline Age $<55$-year-old & 10.348 & 2.416 & 49.900 & 0.004 & 8.903 & 1.705 & 46.478 & 0.010 \\
\hline Body mass index $<23$ & 8.750 & 1.077 & 71.066 & 0.042 & 7.168 & 0.802 & 67.054 & 0.078 \\
\hline Creatinine $<0.6(\mathrm{mg} / \mathrm{mL})$ & 2.724 & 0.696 & 10.654 & 0.150 & 1.603 & 0.337 & 7.617 & 0.553 \\
\hline Drinker & 2.557 & 0.699 & 9.357 & 0.156 & 2.814 & 0.595 & 13.299 & 0.192 \\
\hline Smoker & 0.326 & 0.038 & 2.791 & 0.306 & & & & \\
\hline
\end{tabular}

rate of the guideline-consistent antiemetic medication during overall period was $100 \%$. However, under such a condition, the control of CINV was insufficient: $48 \%$ for complete response, $32 \%$ for complete control, $32 \%$ for the rate of no nausea, and $48 \%$ for the rate of no significant nausea during overall period, although vomiting was well controlled $(78 \%$ for no vomiting during overall period). The rates of control of CINV during overall period observed in the present study were generally consistent with those reported by other investigators in breast cancer patients receiving $\mathrm{AC}$ chemotherapy: the complete response rate was similar to the data $(47 \%)$ by Yeo et al. (12), that $(50 \%)$ by Hesketh et al. (14) and within a range $(36-82 \%)$ reported by others $(8,11$, $13,15,22,23)$. The rates of no nausea and no vomiting were also within the range reported by other investigators [31-49\% for nausea (8-12); 55-92\% for vomiting (9-12, 13-16)].

Risk factors that enhance the incidence of CINV have been reported by several investigators. Younger age is one of risks that reduce the control of CINV (24-30). However, the cut-off age that influences the control of CINV is uncertain. Patients younger than 65 years old $(26,27), 55$ years old $(28,29), 50$ years old $(30)$, or 40 years old $(24,25)$ 
Complete response

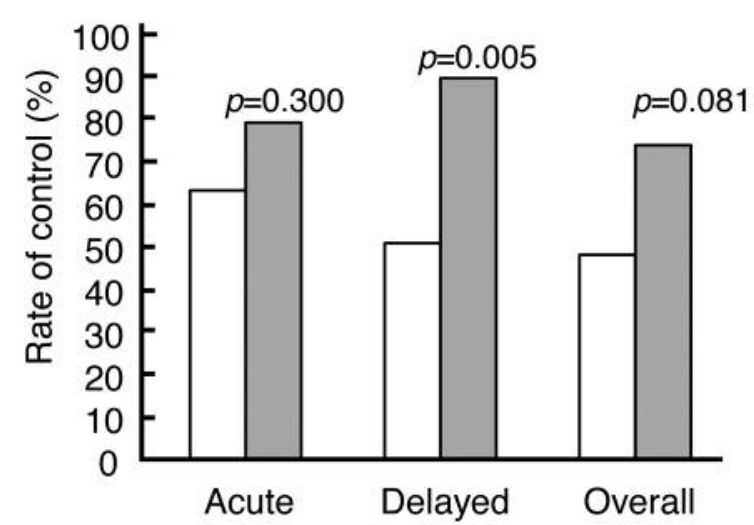

Complete control

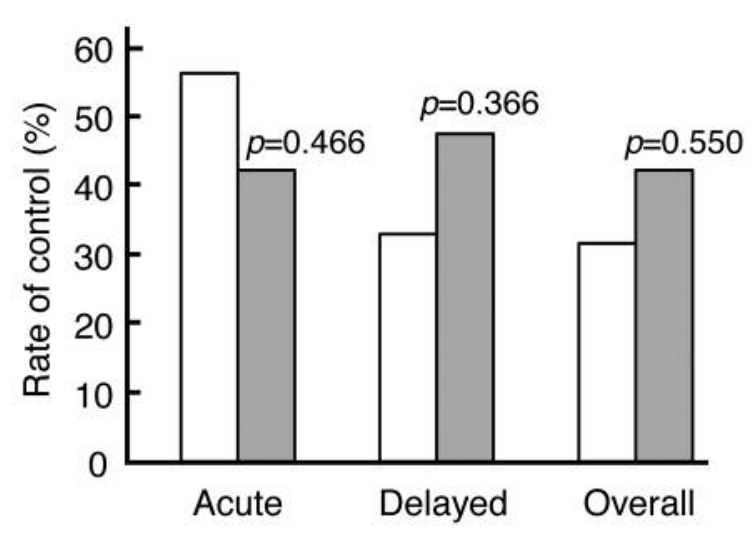

No significant nausea

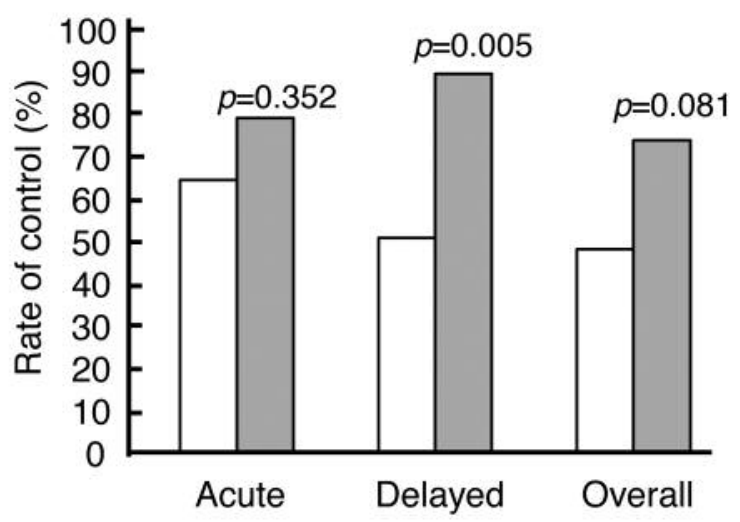

No vomiting

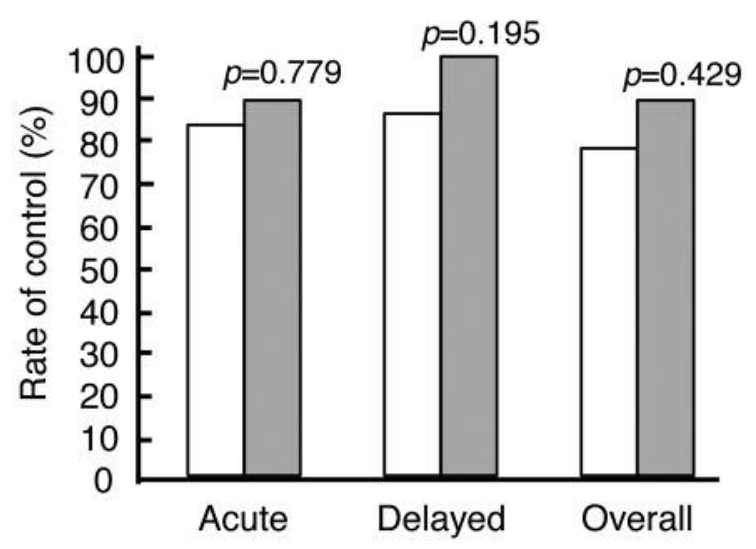

Control ( $\mathrm{N}=73)$

Olanzapine ( $\mathrm{N}=19)$

Figure 2. Effect of olanzapine added to the standard three-drug antiemetic medication on the rates of complete response, complete control, no significant nausea and no vomiting in patients who received the first cycle of AC chemotherapy for breast cancer. Patients in control group were treated with granisetron ( $3 \mathrm{mg}$, intravenously, on day 1), dexamethasone (12 mg, intravenously, on day $1,8 \mathrm{mg} /$ day, orally on days 2-4) and oral aprepitant (125 mg on day 1 and $80 \mathrm{mg} /$ day on days 2-3). Olanzapine was administered orally at $5 \mathrm{mg} /$ day for five consecutive days starting at the day of chemotherapy. Data were statistically compared by the Fisher's exact probability test.

are reportedly more likely to reveal CINV. In the present study, the cut-off value for age was estimated from the Youden index method by the ROC curve analysis. The values were 56.5 years old for nausea and 53.5 years old for vomiting, in which the area under the curve (AUC) was $0.722(95 \% \mathrm{CI}=0.596-0.847)$ for nausea and 0.789 (95\% CI $=0.673-0.906)$, indicating moderate accuracy prediction $(>0.7)$. Then, the values were set to 55 years old for practical use. The present multivariate analysis showed that age younger than 55 years old was a significant risk for nausea $(\mathrm{OR}=4.826 ; 95 \% \mathrm{CI}=1.567-14.865 ; p=0.006)$ and vomiting $(\mathrm{OR}=8.903 ; 95 \% \mathrm{CI}=1.705-46.478 ; p=0.010)$. Our data were similar to the data reported by Warr et al. (31) who showed in breast cancer patients receiving AC chemotherapy that age younger than 55-year-old is significantly associated with enhanced likelihood of vomiting. It was noteworthy that the rates of CINV, including no nausea, no vomiting, complete response and complete control were markedly reduced in patients younger than 55 years old compared with those 55 years old of age and older. It has been reported that $34 \%$ of breast cancer patients are younger than 55 years old (32), although, in the present study, the percentage of 
Table III. Comparison of the control rates of CINV associated with AC chemotherapy between patients whose age was under 55-year-old and those 55 years of age or older.

\begin{tabular}{|c|c|c|c|c|c|c|c|c|}
\hline & \multicolumn{2}{|c|}{ Age $<55$-year-old } & \multicolumn{2}{|c|}{ Age $>55$-year-old } & \multicolumn{3}{|c|}{$95 \% \mathrm{CI}$} & \multirow[t]{2}{*}{$p$-Value } \\
\hline & $\begin{array}{l}\text { Control } \\
\text { rate }\end{array}$ & $\begin{array}{l}\text { (Absence/ } \\
\text { presence) }\end{array}$ & $\begin{array}{l}\text { Control } \\
\text { rate }\end{array}$ & $\begin{array}{l}\text { (Absence/ } \\
\text { presence) }\end{array}$ & OR & Lower & Upper & \\
\hline \multicolumn{9}{|c|}{ Complete response } \\
\hline Acute & $45.9 \%$ & $(17 / 20)$ & $80.6 \%$ & $(29 / 7)$ & 0.205 & 0.072 & 0.585 & 0.005 \\
\hline Delayed & $40.5 \%$ & $(15 / 22)$ & $61.1 \%$ & $(22 / 14)$ & 0.434 & 0.170 & 1.108 & 0.128 \\
\hline Over all & $37.8 \%$ & $(14 / 23)$ & $58.3 \%$ & $(21 / 15)$ & 0.435 & 0.170 & 1.111 & 0.129 \\
\hline \multicolumn{9}{|c|}{ Complete control } \\
\hline Acute & $35.1 \%$ & $(13 / 24)$ & $75.0 \%$ & $(27 / 9)$ & 0.181 & 0.066 & 0.497 & 0.001 \\
\hline Delayed & $16.2 \%$ & $(6 / 31)$ & $50.0 \%$ & $(18 / 18)$ & 0.194 & 0.065 & 0.576 & 0.005 \\
\hline Over all & $16.2 \%$ & $(6 / 31)$ & $47.2 \%$ & $(17 / 19)$ & 0.216 & 0.073 & 0.645 & 0.009 \\
\hline \multicolumn{9}{|l|}{ No nausea } \\
\hline Acute & $37.8 \%$ & $(14 / 23)$ & $75.0 \%$ & $(27 / 9)$ & 0.203 & 0.074 & 0.554 & 0.003 \\
\hline Delayed & $16.2 \%$ & $(6 / 31)$ & $50.0 \%$ & $(18 / 18)$ & 0.194 & 0.065 & 0.576 & 0.005 \\
\hline Over all & $16.2 \%$ & $(6 / 31)$ & $47.2 \%$ & $(17 / 19)$ & 0.216 & 0.073 & 0.645 & 0.009 \\
\hline \multicolumn{9}{|c|}{ No significant nausea } \\
\hline Acute & $48.6 \%$ & $(18 / 19)$ & $80.6 \%$ & $(29 / 7)$ & 0.229 & 0.080 & 0.652 & 0.009 \\
\hline Delayed & $40.5 \%$ & $(15 / 22)$ & $61.1 \%$ & $(22 / 14)$ & 0.434 & 0.170 & 1.108 & 0.009 \\
\hline Over all & $37.8 \%$ & $(14 / 23)$ & $58.3 \%$ & $(21 / 15)$ & 0.435 & 0.170 & 1.111 & 0.129 \\
\hline \multicolumn{9}{|c|}{ No vomiting } \\
\hline Acute & $67.6 \%$ & $(25 / 12)$ & $100 \%$ & $(36 / 0)$ & & & & 0.001 \\
\hline Delayed & $78.4 \%$ & $(29 / 8)$ & $94.4 \%$ & $(34 / 2)$ & 0.213 & 0.042 & 1.085 & 0.098 \\
\hline Over all & $62.2 \%$ & $(23 / 14)$ & $94.4 \%$ & $(34 / 2)$ & 0.097 & 0.020 & 0.466 & 0.002 \\
\hline
\end{tabular}

Table IV. Comparison of demographics of patients between the control and olanzapine group.

\begin{tabular}{|c|c|c|c|c|c|c|c|}
\hline & \multicolumn{3}{|c|}{ Control $(\mathrm{N}=73)$} & \multicolumn{3}{|c|}{ Olanzapin $(\mathrm{N}=19)$} & \multirow[t]{2}{*}{$p$-Value } \\
\hline & Mean & Min & $\operatorname{Max}$ & Mean & Min & $\operatorname{Max}$ & \\
\hline \multirow[t]{2}{*}{ Age } & 54.2 & 25 & 77 & 50.3 & 26 & 73 & $0.220^{\mathrm{a}}$ \\
\hline & Mean & S.D. & & Mean & S.D. & & \\
\hline Body mass index & 21.9 & 3.8 & & 22.3 & 2.7 & & $0.695^{\mathrm{b}}$ \\
\hline Body surface area $\left(\mathrm{m}^{2}\right)$ & 1.51 & 0.14 & & 1.53 & 0.11 & & $0.716^{\mathrm{b}}$ \\
\hline Serum creatinine $(\mathrm{mg} / \mathrm{mL})$ & 0.56 & 0.09 & & 0.53 & 0.09 & & $0.229^{b}$ \\
\hline Dose $\left(\mathrm{mg} / \mathrm{m}^{2}\right)$ & Mean & S.D. & & Mean & S.D. & & \\
\hline Epirubicin (EPI) & 91 & 3 & & 94 & 5 & & $<0.01^{\mathrm{a}}$ \\
\hline Cyclophosphamide(CPA) & 590 & 30 & & 558 & 51 & & $<0.01^{\mathrm{a}}$ \\
\hline Regimens & $\mathrm{N}$ & $\%$ & & $\mathrm{~N}$ & $\%$ & & $0.002^{\mathrm{c}}$ \\
\hline EC (EPI 90/CPA 600) & 63 & 86.3 & & 10 & 52.6 & & \\
\hline FEC (5-FU 500/EPI 100/CPA 500) & 7 & 9.6 & & 8 & 42.1 & & \\
\hline AC (DXR 60/CPA 600) & 3 & 4.1 & & 1 & 5.3 & & \\
\hline
\end{tabular}

aMann-Whitney $U$-test; ${ }^{\mathrm{b}}$-test; ${ }^{\mathrm{c}}$ Kruscal-Wallis test; ${ }^{\mathrm{d}}$ Chi-square test.

patients younger than 55 years old was $51 \%$. Therefore, care should be taken to control CINV in patients receiving $\mathrm{AC}$ chemotherapy for breast cancer.

Olanzapine, an atypical antipsychotic drug, shows high affinity for not only dopamine $\mathrm{D}_{1}, \mathrm{D}_{2}$, and $\mathrm{D}_{4}$ receptors but also $5 \mathrm{HT}_{2 \mathrm{~A}}, 5-\mathrm{HT}_{2 \mathrm{~B}}, 5-\mathrm{HT}_{2 \mathrm{C}}$, and $5-\mathrm{HT}_{3}$ receptors, $\alpha_{1}$-adrenergic receptor, histamine $\mathrm{H}_{1}$ receptor, and muscarinic receptor subclasses $(33,34)$. However, weight gain due to appetite stimulation is a frequent adverse reaction of this compound (18). The enhancement of ghrelin release (35) or ghrelin signaling (36) is considered to be one of mechanisms underlying olanzapine-induced appetite 
stimulation. Navari et al. (19) reported that olanzapine is almost equivalent to aprepitant for the complete response but is more effective than aprepitant for prevention of delayed nausea in patients receiving HEC. Tan et al. (37) also showed by a randomized controlled study comparing the antieffect between olanzapine group (olanzapine 10 $\mathrm{mg}$ /day, days 1-5; azasetron, day 1; dexamethasone, day 1) and control group (azasetron, day 1; dexamethasone, days 1-5) in patients receiving HEC or MEC that olanzapine group is more effective than control group for prevention of delayed nausea. However, few studies have reported the effect of olanzapine added to the standart three-drug antiemetic regimen in breast cancer patients receiving AC chemotherapy. Sato et al. (38) reported in breast cancer patients who experienced nausea or vimiting in a previous AC chemotherapy cycle that nausea is improved by the inclusion of low-dose olanzapine $(2.5 \mathrm{mg} /$ day, days $1-4)$ to the three-drug antiemetic medication in the subsequent chemotherapy cycle. In the present study, the effect of olanzapine (5 mg/day, days 1-5) added to the standard threedrug antiemetic medication was evaluated in breast cancer patients receiving the first cycle of AC chemotherapy, and found that the contol rates of complete response and nausea during delayed period were significantly higher than those of the olanzapine non-treated group.

These findings suggest that addition of olanzapine to the standard three-drug antiemetic medication is potentially useful for the effective control of CINV in breat cancer patients receiving $\mathrm{AC}$ chemotherapy, particularly in patients younger than 55-year-old.

In conclusion, the control of CINV was poor in breast cancer patients receiving AC chemotherapy, in spite of the premedication with the standard three-drug antiemetic regimen. The control rate of delayed nausea was particularly low $(33 \%)$. A multivariate logistic regression analysis indicated that age under 55-year-old was a significant risk for both nausea and vomiting. Olanzapine, when added to the standard antiemetic medication, was highly effective for the improvement of complete response and the control of nausea during delayed period. Therefore, it is suggested that addition of olanzapine to the standard antiemetic medication is potentially useful to improve the control of CINV in patients receiving $\mathrm{AC}$ chemotherapy for breast cancer, particularly in those younger than 55-year-old.

\section{Conflicts of Interest}

The Authors declare no conflict of interest for this research.

\section{Acknowledgements}

This work was supported by JSPS KAKENHI Grant Number JP 17K08441.

\section{References}

1 Fernández-Ortega P, Caloto MT, Chirveches E, Marquilles R, Francisco JS, Quesada A, Suárez C, Zorrilla I, Gómez J, Zabaleta P, Nocea $G$ and Llombart-Cussac A: Chemotherapy-induced nausea and vomiting in clinical practice: impact on patients' quality of life. Support Care Cancer 20: 3141-3148, 2012.

2 Grunberg SM: Obstacles to the implementation of antiemetic guidelines. J Natl Compr Canc Netw 7: 601-605, 2009.

3 Poole CJ, Earl HM, Hiller L, Dunn JA, Bathers S, Grieve RJ, Spooner DA, Agrawal RK, Fernando IN, Brunt AM, O'Reilly SM, Crawford SM, Rea DW, Simmonds P, Mansi JL, Stanley A, Harvey P, McAdam K, Foster L, Leonard RC and Twelves CJ: Epirubicin and cyclophosphamide, methotrexate, and fluorouracil as adjuvant therapy for early breast cancer. $\mathrm{N}$ Engl $\mathrm{J}$ Med 355: 1851-1862, 2006

4 Basch E, Prestrud AA, Hesketh PJ, Kris MG, Feyer PC, Somerfield MR, Chesney M, Clark-Snow RA, Flaherty AM, Freundlich B, Morrow G, Rao KV, Schwartz RN and Lyman GH: Antiemetics: American Society of Clinical Oncology clinical practice guideline update. J Clin Oncol 29: 4189-4198, 2011.

5 National Comprehensive Cancer Network (NCCN) Clinical Practice Guidelines in Oncology (NCCN Guidelines $\left.{ }^{\circledR}\right)$. Antiemesis Version 1.2017: http://www.nccn.org/professionals /physician_gls/pdf/antiemesis.pdf

6 Einhorn LH, Rapoport B, Navari RM, Herrstedt J and Brames MJ: 2016 updated MASCC/ESMO consensus recommendations: prevention of nausea and vomiting following multiple-day chemotherapy, high-dose chemotherapy, and breakthrough nausea and vomiting. Support Care Cancer 25: 303-308, 2017.

7 Takeuchi H, Saeki T, Aiba K, Tamura K, Aogi K, Eguchi K, Okita K, Kagami Y, Tanaka R, Nakagawa K, Fujii H, Boku N, Wada M, Akechi T, Udagawa Y, Okawa Y, Onozawa Y, Sasaki H, Shima Y, Shimoyama N, Takeda M, Nishidate T, Yamamoto A, Ikeda T and Hirata K: Japanese Society of Clinical Oncology clinical practice guidelines 2010 for antiemesis in oncology: executive summary. International J Clin Oncol 21: 1-12, 2016.

8 Schnadig ID, Agajanian R, Dakhil C, Gabrail N, Vacirca J, Taylor C, Wilks S, Braun E, Mosier MC, Geller RB, Schwartzberg L and Vogelzang N: APF530 versus ondansetron, each in a guidelinerecommended three-drug regimen, for the prevention of chemotherapy-induced nausea and vomiting due to anthracycline plus cyclophosphamide-based highly emetogenic chemotherapy regimens: a post hoc subgroup analysis of the Phase III randomized MAGIC trial. Cancer Manag Res 9: 179-187, 2017.

9 Clemons M, Bouganim N, Smith S, Mazzarello S, Vandermeer L, Segal R, Dent S, Gertler S, Song X, Wheatley-Price P and Dranitsaris G: Risk Model-Guided Antiemetic Prophylaxis $v s$. Physician's Choice in Patients Receiving Chemotherapy for EarlyStage Breast Cancer: A Randomized Clinical Trial. JAMA Oncol 2: 225-231, 2016.

10 Hutton B, Clemons M, Mazzarello S, Kuchuk I, Skidmore B and $\mathrm{Ng} \mathrm{T}$ : Identifying an optimal antiemetic regimen for patients receiving anthracycline and cyclophosphamide-based chemotherapy for breast cancer - an inspection of the evidence base informing clinical decision-making. Cancer Treat Rev 41: 951-959, 2015.

11 Roila F, Ruggeri B, Ballatori E, Del Favero A and Tonato M: Aprepitant versus dexamethasone for preventing chemotherapyinduced delayed emesis in patients with breast cancer: a randomized double-blind study. J Clin Oncol 32: 101-106, 2014. 
12 Yeo W, Mo FK, Suen JJ, Ho WM, Chan SL, Lau W, Koh J, Yeung WK, Kwan WH, Lee KK, Mok TS, Poon AN, Lam KC, Hui EK and Zee B: A randomized study of aprepitant, ondansetron and dexamethasone for chemotherapy-induced nausea and vomiting in Chinese breast cancer patients receiving moderately emetogenic chemotherapy. Breast Cancer Res Treat 113: 529-535, 2009.

13 Warr DG, Hesketh PJ, Gralla RJ, Muss HB, Herrstedt J, Eisenberg PD, Raftopoulos H, Grunberg SM, Gabriel M, Rodgers A, Bohidar N, Klinger G, Hustad CM, Horgan KJ and Skobieranda F: Efficacy and tolerability of aprepitant for the prevention of chemotherapy-induced nausea and vomiting in patients with breast cancer after moderately emetogenic chemotherapy. J Clin Oncol 23: 2822-2830, 2005.

14 Hesketh PJ and Sanz-Altamira P: Aprepitant, dexamethasone, and palonosetron in the prevention of doxorubicin/cyclophosphamideinduced nausea and vomiting. Support Care Cancer 20: 653-656, 2012.

15 Hesketh PJ, Younger J, Sanz-Altamira P, Hayden M, Bushey J, Trainor B, Krentzin M, Nowd P, Arnaoutakis K and Hesketh AM: Aprepitant as salvage antiemetic therapy in breast cancer patients receiving doxorubicin and cyclophosphamide. Support Care Cancer 17: 1065-1070, 2009.

16 Aoki S, Iihara H, Nishigaki M, Imanishi Y, Yamauchi K, Ishihara $\mathrm{M}$, Kitaichi K and Itoh Y: Difference in the emetic control among highly emetogenic chemotherapy regimens: Implementation for appropriate use of aprepitant. Mol Clin Oncol 1: 41-46, 2013.

17 Iihara H, Fujii H, Yoshimi C, Yamada M, Suzuki A, Matsuhashi $\mathrm{N}$, Takahashi T, Yoshida K and Itoh Y: Control of chemotherapyinduced nausea in patients receiving outpatient cancer chemotherapy. Int J Clin Oncol 21: 409-418, 2016.

18 Fulton B and Goa KL: Olanzapine. A review of its pharmacological properties and therapeutic efficacy in the management of schizophrenia and related psychoses. Drugs 53: 281-298, 1997.

19 Navari RM, Gray SE and Kerr AC: Olanzapine versus aprepitant for the prevention of chemotherapy-induced nausea and vomiting: A randomized phase III trial. J Support Oncol 9: 188-195, 2011.

20 Akobeng AK: Understanding diagnostic tests 3: Receiver operating characteristic curves. Acta paediatrica 96: 644-647, 2007.

21 Hajian-Tilaki K: Receiver Operating Characteristic (ROC) Curve Analysis for Medical Diagnostic Test Evaluation. Caspian J Intern Med 4: 627-635, 2013.

22 Rugo HS, Rossi G, Rizzi G and Aapro M: Efficacy of NEPA (netupitant/palonosetron) across multiple cycles of chemotherapy in breast cancer patients: A subanalysis from two phase III trials. Breast 33: 76-82, 2017.

23 Kosaka Y, Tanino H, Sengoku N, Minatani N, Kikuchi M, Nishimiya H, Waraya M, Katoh H, Enomoto T, Sato T, Kuranami $\mathrm{M}$ and Watanabe M: Phase II randomized, controlled trial of 1 day versus 3 days of dexamethasone combined with palonosetron and aprepitant to prevent nausea and vomiting in Japanese breast cancer patients receiving anthracycline-based chemotherapy. Support Care Cancer 24: 1405-1411, 2016.

24 Booth CM, Clemons M, Dranitsaris G, Joy A, Young S, Callaghan W, Trudeau M and Petrella T: Chemotherapy-induced nausea and vomiting in breast cancer patients: a prospective observational study. J Support Oncol 5: 374-380, 2007.

25 Fraunholz I, Grau K, Weiss C and Rödel C: Patient- and treatment-related risk factors for nausea and emesis during concurrent chemoradiotherapy. Strahlenther Onkol 187: 1-6, 2011.
26 Hesketh PJ, Aapro M, Street JC and Carides AD: Evaluation of risk factors predictive of nausea and vomiting with current standard-of-care antiemetic treatment: analysis of two phase III trials of aprepitant in patients receiving cisplatin-based chemotherapy. Support Care Cancer 18: 1171-1177, 2010.

27 Hilarius DL, Kloeg PH, van der Wall E, van den Heuvel JJ, Gundy CM and Aaronson NK: Chemotherapy-induced nausea and vomiting in daily clinical practice: a community hospital-based study. Support Care Cancer 20: 107-117, 2012.

28 Tamura K, Aiba K, Saeki T, Nakanishi Y, Kamura T, Baba H, Yoshida K, Yamamoto N, Kitagawa Y, Maehara Y, Shimokawa M, Hirata $\mathrm{K}$ and Kitajima M: Testing the effectiveness of antiemetic guidelines: results of a prospective registry by the CINV Study Group of Japan. Int J Clin Oncol 20: 855-865, 2015.

29 Sekine I, Segawa Y, Kubota K and Saeki T: Risk factors of chemotherapy-induced nausea and vomiting: index for personalized antiemetic prophylaxis. Cancer Sci 104: 711-717, 2013.

30 Aapro M: Optimising antiemetic therapy: what are the problems and how can they be overcome? Curr Med Res Opin 21: 885-897, 2005.

31 Warr DG, Street JC and Carides AD: Evaluation of risk factors predictive of nausea and vomiting with current standard-of-care antiemetic treatment: analysis of phase 3 trial of aprepitant in patients receiving adriamycin-cyclophosphamide-based chemotherapy. Support Care Cancer 19: 807-813, 2011.

32 Breast Cancer Facts \& Figures 2009-2010. https:// www.cancer.org/content/dam/cancer-org/research/cancer-factsand-statistics/breast-cancer-facts-and-figures/breast-cancer-factsand-figures-2009-2010.pdf\#search $=\% 27$ Breast + Cancer + Facts + \%26+Figures+20092010\%27. Accessed on 31 August 2017.

33 Bymaster FP, Calligaro DO, Falcone JF, Marsh RD, Moore NA, Tye NC, Seeman P and Wong DT: Radioreceptor binding profile of the atypical antipsychotic olanzapine. Neuropsychopharmacol 14: 87-96, 1996.

34 Shahid M, Walker GB, Zorn SH and Wong EH: Asenapine: a novel psychopharmacologic agent with a unique human receptor signature. J Psychopharmacol 23: 65-73, 2009.

35 Palik E, Birkás KD, Faludi G, Karádi I and Cseh K: Correlation of serum ghrelin levels with body mass index and carbohydrate metabolism in patients treated with atypical antipsychotics. Diabetes Res Clin Pract 68: S60-64, 2005.

36 Tagami K, Kashiwase Y, Yokoyama A, Nishimura H, Miyano K, Suzuki M, Shiraishi S, Matoba M, Ohe Y and Uezono Y: The atypical antipsychotic, olanzapine, potentiates ghrelin-induced receptor signaling: An in vitro study with cells expressing cloned human growth hormone secretagogue receptor. Neuropeptides 58 : 93-101, 2016.

37 Tan L, Liu J, Liu X, Chen J, Yan Z, Yang H and Zhang D: Clinical research of Olanzapine for prevention of chemotherapy-induced nausea and vomiting. J Exp Clin Cancer Res 28: 131, 2009.

38 Sato J, Kashiwaba M, Komatsu H, Ishida K, Nihei S and Kudo $\mathrm{K}$ : Effect of olanzapine for breast cancer patients resistant to triplet antiemetic therapy with nausea due to anthracyclinecontaining adjuvant chemotherapy. Jpn J Clin Oncol 46: 415-420, 2016.

Received November 9, 2017

Revised November 24, 2017

Accepted November 27, 2017 